\title{
The Influence of Earth Science Community Learning Model (EARTHCOMM) to Learning Outcomes of Geography
}

\author{
Mei Vita Romadon Ningrum ${ }^{1}$, Ernia Kholiq ${ }^{2}$, \\ ${ }^{1,2}$ Geography Education Studies Program Faculty of Teacher Training and Education Mulawarman University \\ East Kalimantan, Indonesia \\ mei_vita88@yahoo.com¹, ernia_kholiq@yahoo.com²
}

\begin{abstract}
The learning model of Earth Science Community (Earthcomm) is a learning process that is more concerned with students' activeness in solving problems and finding ideas to build an understanding of knowledge they have acquired. The purpose of this study was to determine the influence of the results of Earthcomm learning model to learning outcomes of geography on materials such as exploration, exploitation of minerals and reclamation of the mine site of the former class XI at Madrasah Aliyah Negeri 2 Samarinda. This research is a quantitative research with experimental research design. In this research there are independent variable which is the model of learning Earth Science Community $(\mathrm{X})$ and the dependent variable which is the learning outcomes (Y). The population in the study were all students of class XI MAN 2 Samarinda in Academic Year 2015/2016. The sampling technique used purposive sampling technique. The sample in this study were students of class XI IPS-2 which consist of 30 students. Collecting data in this study use questionnaire to determine the students' response to the model and test techniques is to measure students' learning outcomes after using Earthcomm model. The results showed the average value of students after using the Earthcomm learning model included in both categories with a value of 84.76 . The correlation of coefficient is 0.802 and 50.615 , with significance level of 0.000 . Specifically, the level of significance is lower than the significance level of $5 \%$ or 0.05 , so that makes significant relationship between Earthcomm learning model to the learning outcomes of students MAN 2 Samarinda. The coefficient of determination obtained 0.644 , which means the application of Earthcomm learning model affect $64 \%$ to the students' learning outcomes with regression calculation equation of $\mathrm{Y}=12,095 \mathrm{X}+$ 0,548 .
\end{abstract}

Keywords-Earth Science Community (Earthcomm), Learning model, \& Geography Learning Outcomes

\section{INTRODUCTION}

The goal of Geography learning is aligned with national education objectives. The learning of Geography has a meaningful learning objective for learners' life, within the sphere of social life, social life and natural living environment. Teacher professional development continues to suggest that these changes can be achieved through the implementation of research-based practices and consequently improve student learning [1,2]. Geography builds and develops learners' understanding to understand the physical aspects and processes that shape the earth's patterns, the characteristics and the spatial distribution of the ecology on the surface of the earth. In addition, Geography provides students with knowledge about the earth with spatial, environmental and territorial approaches. From the learning of Geography, the students are expected to be able to provide problem solving related to human interaction and natural environment. In the subject matter of Geography at High Schools, there are exploratory subject, mining exploitation and reclamation of ex-mining location which are materials that requires learners to relate between material learned and real-life every day, whether in family environment, school, community and citizen, with the purpose of discovering the meaning of matter for his life [9].

To achieve optimal learning outcomes on Geography subjects, it cannot be separated from various problems, especially in the process of teaching and learning, from the results of interview and observation of learning in Madrasah Aliyah Negeri 2 Samarinda there are several issues raised: (1) The number of subject matters that must be submitted in a relatively short period of time. (2) Many students know or memorize the subject matter, but unable to apply and relate knowledge to the natural living environment. (3) The process of Geography learning tends to be verbal, less involving the facts, not using media and technology that helps to facilitate the understanding of learners. (4) Less in relation to Geography subject matter in solving current problems. (5) The lack of variety of models and media used in the learning process.

These problems need to have an improvement or variation in terms of new learning model, which can stimulate learners to learn and improve thinking skills in terms of reasoning, communicating and solving an existing problem in the environment. Appropriate learning model applied for high school related to Geography lesson is Earth Science Community (EarthComm) learning model. Study system represent a bow outlines in activity of study to reach target which have been marked with lines [3]. In line with this definition, [4] points out that: "Study of constructivism theory is study instructing student to obtain; get knowledge and build its understanding pursuant to horizon and experience with lesson items". That is, Earthcomm theory learning is a learning that leads students to gain knowledge and build their understanding based on experience and insight relating to the subject matter [8].

The EarthComm learning model applied materials exploration, exploitation of minerals and reclaimed ex-mine sites aims to provide learners with more opportunities in 
shaping material concepts, finding images through experience in group collaboration in the learning process to improve understanding of the material delivered. This learning is often oriented to textbooks and mastery of memorization of the textbook content. This resulted in the success of learners to remember what is listed in the textbook [6]. Shortly, it is not enough where the learning outcome is to make the students have the ability just in memorization, but how capable learners think about the problems that exist in the environment. As well as mining problems in the region of Samarinda. From the application of EarthComm learning model, learners are expected to not only know what it is, but how to do things and how to connect with the real life and to know what role they should play in the environment, critical of natural resource wealth and problems in the environment. This background makes the researchers consider to conduct a study on "The Influence of Earth Science Learning Model Earthcomm (Earthcomm) to Students' Learning Outcomes at Madrasah Aliyah Negeri 2 Samarinda".

\section{Methodology}

This research is a kind of quantitative research because this research uses formal instruments, standard and measuring [7]. The method of this research is quantitative causal relation. This is because the formulation of research problems is causal. So there are independent variable that is learning model Earth Science Community (Earthcomm) and dependent variable that is result of student learning [5]. This research was conducted in Madrasah Aliyah Negeri 2 Samarinda located at Jalan Harmonika No 98 Samarinda in the odd semester of 2015/2016 study year. Subjects in this study were students of class XI IPS2 MAN 2 Samarinda amounted to 30 students.

Data collection techniques above, then in this research will be used techniques as follows: Test, Questionnaire, and Observation. The appropriate data collection tool used in this study:

\section{- Test Results Learning}

- Questionnaire to response the Earthcomm Learning Model

- Observation sheet in the application of this learning method which is included the following:

\section{A. Observation sheet of teacher activity}

This observation sheet to find out the description of the implementation of teacher action in Geography learning in class by applying this method of learning

\section{B. Student observation sheet}

This observation sheet to know the description of student activity during the students ongoing learning process of geography taught by using this learning method to know the influence of Earth Science Community learning model to the students' geography learning result, simple linear regression, correlation, determination of coefficient of determination and statistical test is done by testing the hypothesis using $F$ test with significance test rule if Fcount is greater than Ftable then Hypothesis Ho is rejected and Ha is accepted and if Fcount is smaller than Ftable then Hypothesis Ho accepted and $\mathrm{Ha}$ rejected.

\section{RESULT AND DISCUSSION}

This study used questionnaire to determine students' responses to the Earthcomm learning model on geography learning. The researcher obtained that the total response of questionnaire score was 132.7 with average score was 4.42. These results indicate that the use of the Earthcomm learning model falls into either category Student learning outcomes data obtained average score of 84 with a KKM value of 75 . This result indicates that the average value of student learning outcomes is higher than the minimum completeness criteria (KKM) that has been determined by the school.

\section{TABLE I. LEARNING OUTCOME DATA OF STUDENT}

\begin{tabular}{|l|l|l|l|}
\hline Score & Category & frequency & $\%$ \\
\hline $86-100$ & Excellent & 17 & 57 \\
\hline $76-85$ & Good & 9 & 30 \\
\hline $60-75$ & Fair & 4 & 13 \\
\hline $55-59$ & Low & 0 & 0 \\
\hline $0-54$ & Very Low & 0 & 0 \\
\hline
\end{tabular}

From the analysis of Earthcomm learning model to the students' geography learning outcomes through the learning process, the researchers obtained percentage of students who have completed in the material exploration, exploitation of mining and reclamation of ex-mining location is $86 \%$. With details of 26 students who have completed in the learning of 30 students. Student learning completeness is based on KKM School in geography subject that is 75 . Because the percentage of students who complete on exploration material, mining exploitation and reclamation of $86 \%$ former mine location, the learning is said to be successful. This is indicated by the magnitude of the influence of Earthcomm learning model on student learning outcomes of $64.4 \%$. There is a contribution to the influence of the Earthcomm learning model on learning outcomes. So if the Earthcomm learning model gets higher, then concept understanding will increase as well.

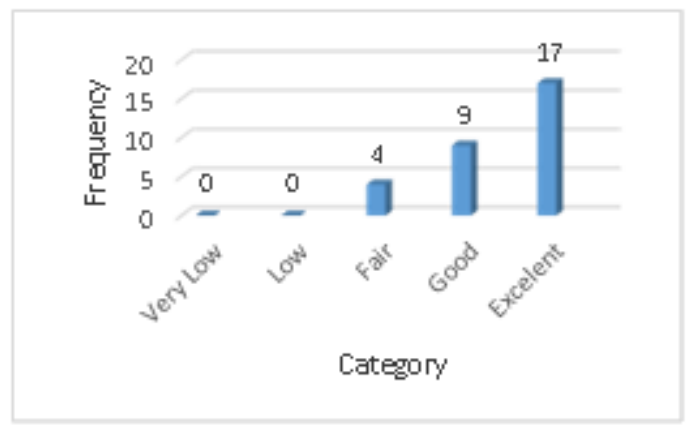

Fig. 1. The result of data analysis prove earthcomm increased a learning outcome student

From the calculation of correlation coefficient obtained $r$ value of 0.802 . Based on the criteria that have been used, it can be concluded that the Earthcomm learning model and the students' geography learning outcomes have a very strong correlation. Coefficient of determination value in this research 
is $\mathrm{D}=0,644$. Then, coefficient of determination showed $64.4 \%$ student learning outcomes influenced by the use of EarthComm learning model and the rest $35.6 \%$ learning outcomes are influenced by other factors.

TABLE II. ANALYSIS OF VARIACE (ONE- WAY ANOVA)

\begin{tabular}{|c|c|c|c|c|c|c|c|}
\hline \multicolumn{8}{|c|}{ One Way Anova } \\
\hline \multirow[t]{2}{*}{ Subject } & \multirow{2}{*}{$\begin{array}{l}\text { Sum of } \\
\text { Square } \\
\text { Fobs }\end{array}$} & \multicolumn{3}{|c|}{ Result } & \multicolumn{2}{|c|}{ Information } & \multirow{2}{*}{$\begin{array}{l}\text { Decisio } \\
\mathrm{n}\end{array}$} \\
\hline & & Df & Sig & $\begin{array}{l}\text { Ftab } \\
0,05\end{array}$ & Ftable & Sig & \\
\hline $\begin{array}{ll}\text { XI IPS- } \\
2\end{array}$ & 50,615 & 28 & 0,00 & 4,20 & $\begin{array}{l}\text { Fobs }> \\
\text { Ftab }\end{array}$ & $\begin{array}{l}0,00 \\
\leq \\
0,05\end{array}$ & $\begin{array}{l}\mathrm{H} 0 \\
\text { Rejecte } \\
\mathrm{d}\end{array}$ \\
\hline
\end{tabular}

From the calculation result, the value of coefficient of intersap estimator (a) is 12,095 and the value of regression coefficient $(0,048)$ so that the linear regression equation is $\mathrm{Y}=$ $12,095 \mathrm{X}+0,548$ The value of interception estimator and the intercept coefficient is obtained from the combination of EarthComm learning model scores and the result score learning class XI IPS-2 students The above equation shows the effect of EarthComm learning model on geography learning result.

\section{CONCLUSION}

Based on the results of research and data analysis that has been done in MAN 2 Samarinda in class XI IPS-2 on the influence of Earthcomm learning model on learning outcomes, it can be deduced that from the output $\mathrm{F}$ on the annova table with a significant level $(\alpha) 5 \%$ Fcount of 50,615 which more than Ftable 4,20 can be concluded that there is significant influence of Earthcomm learning model to the students' geography result on exploration material, mining exploitation and reclamation of second class XI IPS-2 MAN 2 Samarinda year of learning 2015 / 2016. Thus it can be interpreted that H0 is rejected or in other words the proposed hypothesis can be accepted and the amount of contribution given by Earthcomm learning model, to the learning outcomes of $64.4 \%$ while
$35.6 \%$ student learning outcomes are influenced by other factors that are not measured in this study.

\section{REFERENCES}

[1] D. Jonassen, M. Davidson, M. Collins, J. Campbell, and B. B. Haag, "Constructivism and Computer-Mediated Communication in Distance Education," Am. J. Distance Educ., vol. 9, no. 2, pp. 7-26, 1995.

[2] Suherdiyanto, "Efforts to Improve Student Learning Outcomes through Earth Science Community (Earthcomm) Learning," J. Pendidik., vol. 1, no. 1, pp. 111-123, 2014.

[3] Sumarmi, Geography Learning Models. Malang: Aditya Media, 2012.

[4] H. F. O’Neil, R. Wainess, and E. L. Baker, "Classification of learning outcomes: evidence from the computer games literature," Curric. J., vol. 16, no. 4, pp. 455-474, 2005.

[5] S. B. Eom, H. J. Wen, and N. Ashill, "The Determinants of Students' Perceived Learning Outcomes and Satisfaction in University Online Education: An Empirical Investigation*," Decis. Sci. J. Innov. Educ., vol. 4, no. 2, pp. 215-235, 2006.

[6] J. Suprihatiningrum, Learning Plan. Yogyakarta: Ar-Rum Media, 2013.

[7] M. P. Rice, G. C. O\&apos;Connor, and R. Pierantozzi, "Implementing a learning plan to counter project uncertainty," IEEE Eng. Manag. Rev., vol. 36, no. 2, pp. 92-102, 2008.

[8] A. . Sardiman, Interaction \& Motivation of Teaching and Learning. Jakarta: PT. Raja Grafindo Persada, 2007.

[9] D. R. Krathwohl, "A Revision of Bloom's Taxonomy: An Overview," Theory Pract., vol. 41, no. 4, pp. 212-218, 2002.

[10] M. Lodico, D. Spaulding, and K. Voegtle, Methods in educational: From theory to practice, vol. 1. 2006.

[11] K. N. Barker, "Data collection techniques: observation.," Am. J. Hosp. Pharm., vol. 37, no. September, pp. 1235-1243, 1980.

[12] M. Sandelowski, "Combining qualitative and quantitative sampling, data collection, and analysis techniques in mixed-method studies.," Res. Nurs. Health, vol. 23, no. 3, pp. 246-255, 2000. 